\title{
A PARTNERSÉGI ÉS HAGYOMÁNYOS KÉPZÉSŰ HALLGATÓK ÉLETPÁLYAKÉPE A KÉPZÉS ELEJÉN
}

\section{PROFESSIONAL IMAGE OF STUDENTS TAKING PART IN THE TRADITIONAL AND PARTNERSHIP TRAINING AT THE BEGINNING OF THE TRAINING}

\author{
Sági Norberta ${ }^{1^{*}}$ \\ ${ }^{1}$ Idegennyelvi és Továbbképzési Tanszék, Pedagógusképző Kar, Neumann János Egyetem, Magyarország \\ https://doi.org/10.47833/2020.2.ART.003
}

\section{Kulcsszavak:}

pedagógusképzés,

pályaszocializáció,

életpályakép,

tanító szak

\section{Keywords:}

teacher training, professional socialisation, professional image, primary school teacher's profession

\section{Cikktörténet:}

Beérkezett 2020. március18.

Átdolgozva 2020. április 10.

Elfogadva 2020. április 20.

\begin{abstract}
Összefoglalás
2019 szeptemberében a pedagógusképzés új, a duális képzési formához hasonló modellje indult el a NJE PK-n. Az elmélet és munkahelyi gyakorlat időbeli ütemezése igazodik a köznevelés igényeihez, és lehetővé teszi a hallgató számára az elméleti ismeretek és a gyakorlat harmonizálását. Ezzel egyidőben megvalósul a pályaszocializáció. A tanulmány bemutatja az új képzési modellben tanuló hallgatók életpályaképénék jellegzetes vonásait és a hagyományos képzésben résztvevő hallgatók életpályaképével szembeni különbségeket.
\end{abstract}

\begin{abstract}
A new model of teacher training similar to the dual education was established at NJE PK in September 2019. The theoretical lessons and the workplace practice are scheduled to meet the needs of public education, and this system makes it possible for the students to harmonise the theoretical knowledge with the practice. At the same time the professional socialisation takes place. The study shows the typical features of those students' professional images who study in the new system and those who study in the traditional system and the differences between two groups.
\end{abstract}

\section{Bevezetés}

„Az alapfokú oktatás minőségének elemzése és értékelése minduntalan ráirányítja a figyelmünket arra, hogy más, e kérdéskört érintő gazdasági, politikai, szociális és pszicho- pedagógiai tényezőkön túlmenően, annak optimalizálása a pedagógusképzési rendszer elemzését és korszerüsitését is feltételezi. Úgy is fogalmazhatnánk, hogy a pedagógus-képzés minősége az oktatás minőségét tükrözi."[1]

\footnotetext{
* Kapcsolattartó szerző. E-mail cím: sagi.norberta@pk.uni-neumann.hu
} 


\section{2. Új tanítóképzési modell megjelenése a kecskeméti NJE Pedagógusképző Karán}

\subsection{Pedagógusképzés és tanítóképzés}

Bármely, pedagógusszakmára felkészítő képzést vizsgáljuk, a képzések általános komponensei között találjuk a pedagógiai és pszichológiai ismereteket, a szaktudományos felkészítést, a szakmódszertant és tantárgypedagógiát, valamint a gyakorlati felkészítést. Ezek arányát, struktúráját az adott szakok képzési és kimeneti követelményei határozzák meg.[2]

A pedagógiai tudományos közéletnek, a felsőoktatási intézmények kutatóinak, oktatóinak köszönhetően a pedagógusképzésben a hivatást, a szakmát formáló, politikai tartalmú tananyagok, tantárgyak nagy váltása a 90-es évekre megtörtént. A megújulás, a tartalmi fejlesztés tehát részben időbeli folyamat, a különböző modellek megjelenése a köznevelési színterek igényeire válaszolva máig folyamatosnak mondható, $s$ az utóbbi idöben javarészt különböző pályázati forrásoknak köszönhetően valósult meg. A fő csapásiránytól eltérő tartalmi modellek megjelenését, a tartalmi modellek párhuzamos létezését indokolja például a reformpedagógiai irányzatok által igényelt pedagógusképzés. Általánosságban azt mondhatjuk, hogy a pedagógusképzés különböző szerkezeti modelljeinek állandó elemei a következők: az általánosan müvelő (értelmiségi létre nevelö) tantárgyak, a szakos jellegű tudományos ismereteket nyújtó tantárgyak és a pedagógusi kultúrát, mesterséget meghatározó elméleti és gyakorlati tantárgyak. A pedagógusképzésben e modulok tartalma határozza meg a képzés makrostruktúráját, a végzettséget. A pedagógusképzés mikrostruktúráját azok a nagyobb képzési egységek határozzák meg, amelyek egy adott szak képesítési követelményeiben megfogalmazódnak és az adott végzettség komponensei.[3]

A tanító szak gyakorlati képzésében a hospitálási tevékenység és a tanítási gyakorlatok keretében a hallgatók megfigyeléseket, elemző tevékenységet végeznek, s egyes nevelési-oktatási feladatokat látnak el. Ennek feltételeit a pedagógusképző egyetem / főiskola saját, felsőoktatási irányítással müködő gyakorló iskolájában vagy partnerintézményében biztosítja, vagy hozzájárul ahhoz, hogy a hallgató az általa választott iskolában, és a törvényi előírásnak megfelelő pedagógus felügyelete, mentorálása mellett teljesítse a gyakorlati képzéshez kapcsolódó iskolai feladatait.

\subsection{A partnerségi képzési forma bevezetése}

A 2019 őszén bevezetett partnerségi tanítóképzés a duális képzési formához hasonló elvekre épül, vagyis a hallgató egyetemi tanulmányaival párhuzamosan a szakjának megfelelő munkahelyi gyakorlatra tesz szert. Az időbeli ütemezés azonban eltér a duális képzésétöl és a köznevelés igényeihez igazodik. Az első évben három nap egyetemi képzést két munkahelyen töltött nap követ. Ez az időbeli ütemezés lehetővé teszi a hallgató számára az elméleti ismeretek és a gyakorlat harmonizálását, valamint az iskolai feladatokban való közremüködést. A partnerségis munkahelyen (általános iskola) a partnerségis hallgatót az adott tankerület pedagógiai asszisztensként alkalmazza. A munkakörhöz az egyetemi képzés sajátosságait is figyelembe vevő munkaidőbeosztás kapcsolódik, mely a pedagógiai asszisztens jelenlétét az általános iskola számára is jól tervezhetővé teszi: minden csütörtökön és pénteken számol(hat)nak a munkájával, ezen felül pedig a vizsgaidőszakban, illetve oktatási szünetekben tud részt venni az iskola életében.

Az új képzési modell bevezetésével az a törekvése a NJE Pedagógusképző Karának, hogy a pályára kerülök „startcsomagjában” olyan ismeretek, jártasságok, készségek, valamint olyan attitüdök legyenek, melyek egy leendő tanító számára megfelelő alapot jelentenek tanítói életpályaképének megalkotásához. A képzéssel egyidőben megvalósul a pályaszocializáció is.

\section{A pedagóguspályát választók néhány jellemzője}

A pedagóguspályát választók vizsgálata már több szempontból megtörtént az elmúlt években. Szemerszki Marianna országos adatelemzéséből tudjuk, hogy a pedagógusképzésre (minden pedagógusképzéshez tartozó alap- és mesterszak) jelentkezők között többségben vannak a kisebb városokból, községekböl felvételizők. A településtípus szerinti eltérések, néhány területi mutató és 
a hátrányos helyzetért kapható többletpontok igénylése azt a korábbi vélekedést erősíti meg, hogy a pedagógusképzés választása országos viszonylatban gyakran a társadalmi felemelkedést segíti. $\mathrm{Az}$ adatsorok szerint a pedagógusképzésben jelentős az első generációs értelmiségiek aránya, amellett, hogy természetesen jellemző a szakma átörökítése is. [4]

Veroszta Zsuzsanna [5] felsőoktatási jelentkezés előtt álló középiskolásokat vizsgált azzal a céllal, hogy azonosítsa azokat a jelentkezői csoportokat a pedagóguspályakép szerepének elemzése révén, amelyek körében nagyobb valószínüségű lehet a pedagóguspálya választása. Közismert, hogy a pedagógusképzés ma nem népszerű a középiskolások körében. Elönyei - más diplomás pályákhoz képest - alapvetően a családdal való összeegyeztethetőség, a biztosabb munkahely, a társadalmi hasznosság, de ellene szól a szakma alacsony presztízse, az alacsony jövedelem és a karrierlehetőségek hiánya. A pályaorientációs munka során, az életpályatervezéskor a tanuló mindezeket a szempontokat figyelembe véve nem csupán a következő lépést (egy adott szak kiválasztását) tervezi meg (szülö, pedagógus segítségével), hanem már az azt követő lépéseket is, akár a teljes aktív munkában töltött életszakaszt. A tervezéshez segítséget nyújt a pedagógus-életpályamodell, mely kijelöli a pedagógus életút egyes állomásait, de a középiskolások számára oly kevés információ áll rendelkezésre róla, s az információk többsége oly negatív megítéléssel párosul, hogy az a pályaválasztás előtt álló középiskolások számára nem karrierlehetőséget, hanem megfelelési kötelezettséget jelent.

A pedagóguspályát választók fentebb említett jellemzőin túl Veroszta kutatásából kiemeljük azt a megállapítást, miszerint a kiváló eredményekkel, intellektuális képességekkel rendelkező hallgatók kisebb valószínüséggel lépnek a pedagóguspályára, mint társaik, de leszögezi, hogy ez a képesség alapú kontraszelekció az egyes szakokon és pedagógusfoglalkozásokon belül is eltérő.

A pedagóguspályákon a nők erősen felülreprezentáltak. A nemi alapú szelekció ugyanakkor nem csupán a pályaválasztáskor nyilvánul meg, hanem a pályára lépéskor újra kimutatható. $A$ végzett férfi pedagógusok többségükben más pályát választanak. Mint Veroszta rámutat [6], a pedagógusfoglalkozásokon belüli jelentős női aránynak lehet munkaerőpiaci hatása. Ez (is) okozhatja a pályaválasztó nők közötti minőségi kontraszelekciót, melynek során a tehetségesebbek más pályát választanak. Másfelöl felértékelheti a pedagóguspályának azon jellemzőit, melyek a más női szerepekben való helytállást elősegíthetik: pl. rugalmasabb időbeosztás, gyermeknevelési idő, s ezek is pályaválasztás motivációjává válhatnak.

Mind ezek a megállapítások a NJE Pedagógusképző Karának hallgatói állományára is igazak, ezért megismétlésüktől eltekintünk. Az intézményünk beiskolázási területét elsősorban a környező települések, az alföldi régió, a Budapest-Szeged-Debrecen háromszög középső része jelenti. $A$ hallgatóink többsége számára fontos, hogy a pedagógusképzésben államilag finanszírozott képzésformában tanulhatnak, mert a családok többnyire nem tudnák vállalni a képzés költségeit. $\mathrm{A}$ felsőoktatási tanulmányok mellett, még nappali tagozaton is a hallgatók nagy hányada kényszerül munkavállalásra annak érdekében, hogy költségeinek fedezetét biztosítani tudja. A tanulás és munkavállalás egyidejüleg többszörös terhelést jelent, melyből szorult esetben a munkavállalás marad és a tanulást függeszti fel a hallgató.

\section{Elsőéves tanító szakos hallgatók életpályaképe (továbbtanulás, szakmai siker, kudarc)}

Mindezen gondolatok után felvetődik a kérdés, hogy a pedagógusképzést választó, tanító szakon tanuló első éves hallgatók milyen életpályaképpel rendelkeznek? Van-e különbség az első szemeszter 3. hónapjában a hagyományos (nem partnerségi) és a partnerségi képzésben tanuló hallgatók elképzelései, tervei között?

A papír alapú kérdőív 14 kérdést tartalmazott, melyek zöme nyitott kérdés volt. A kérdések a tanítói pálya választásának motivációjára, a tanítói pályáról alkotott előzetes elképzelésekre és jelenlegi véleményre, a szakmai irányú továbbképzési motivációra irányult. A kérdőív nyitott kérdésben vizsgálta azt, hogy a hallgató a diplomaszerzést követően, majd 2 és 5 évvel a diplomaszerzés után hogyan látja és tervezi szakmai életútját, és mik a távolabbi tervei. 
Többválasztásos kérdések vizsgálták azt, hogy mi annak az oka, ha a hallgató diplomaszerzést követően tanítóként szeretne elhelyezkedni, illetve melyek azok az okok, amelyek őt ettől eltéríthetik.

A kérdőíves vizsgálatban a NJE Pedagógusképző Karának első éves, tanító szakos, nappali képzésben résztvevő hallgatói vettek részt. Az évfolyam 30 föből áll, átlagéletkoruk $20 \mathrm{év}$. $A z$ évfolyam 40\%-a partnerségi képzésben vesz részt, mely azt jelenti, hogy hetente 3 napot egyetemi órákon vesznek részt, 2 napot pedig egy általános iskolában pedagógiai asszisztensi munkakörben dolgoznak.

A felmérést az a hipotézis indokolta, hogy a partnerségi és hagyományos képzésben résztvevő hallgatók tanítói életpályaképe között már a képzés elején, 3 hónap után különbségek mutathatók ki. Ezt arra a feltételezésre alapoztuk, hogy a partnerségi képzésben résztvevő hallgatók korai munkahelyi tapasztalataik, „pályán” töltött idejük miatt (még ha ez nem is tanítói, hanem pedagógiai asszisztensi munkakör is), eltérő elképzelésekkel rendelkeznek a diplomaszerzést követő szakmai elömenetelükröl.

A diplomaszerzést követő továbbtanulási terveket tekintve két különbség szembeötlö. A hagyományos képzésben résztvevő hallgatók csaknem fele (46\%) látja úgy, hogy diplomaszerzést követő 1-2 éven belül továbbképzésen vesz részt, 15\%-uk nem gondol egyelöre erre. A partnerségis hallgatóknál kisebb azok aránya, akik a továbbtanulásra még nem gondolnak vagy a továbbtanulást 1-2 éven belül tervezik, ugyanakkor nagyobb azok aránya, akik az anyagi lehetőségeiktöl (22\%) vagy a munkahelyi elvárásoktól (22\%) tennék ezt majd függővé (1-2.ábra).
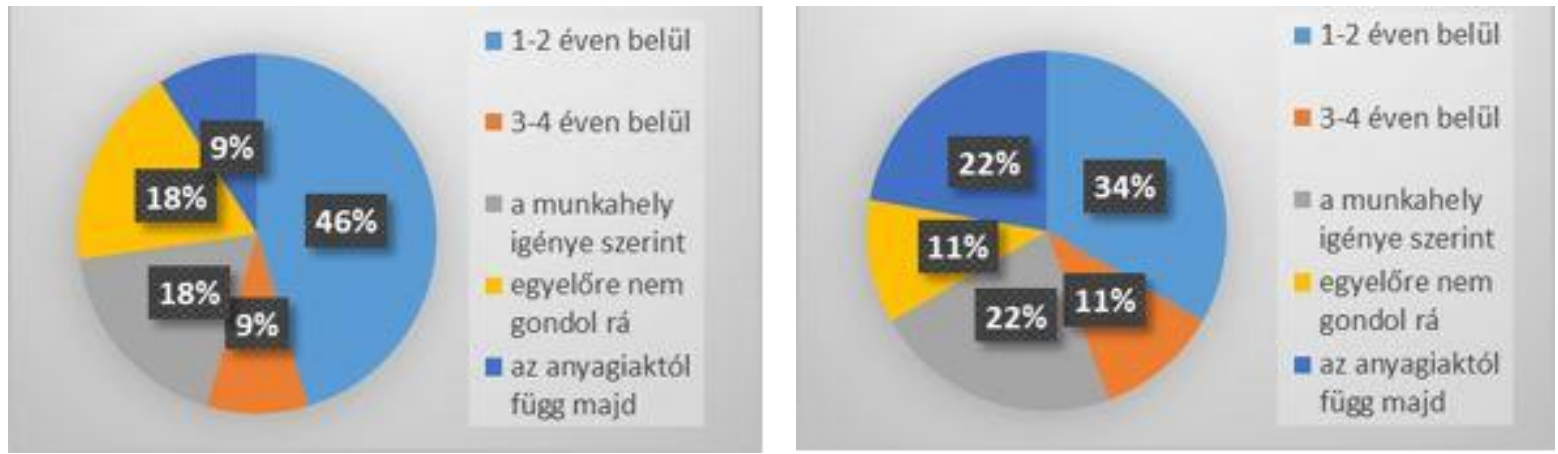

1-2.ábra A nem partnerségi és partnerségi képzésben résztvevők továbbtanulási tervei diplomaszerzés után (2019)

A továbbtanulási tervek kapcsán felmerül annak kérdése, hogy milyen képzést választanának a hallgatók. Alapvetően két jellemző válasz született: egyrészt a pedagógián belüli specializálódás (például gyógypedagógia, logopédia, pedagógia vagy egy tanári MA szak), másrészt a pedagógiától és a tanító szaktól eltérő képzési irány (pénzügy, kereskedelem), ami a képzés elején igen meglepő. Ezek részletes elemzésére azonban itt nem térünk ki.

A következőkben azt mutatjuk be, hogy az első éves hallgatók mit tartanak egy tanító legfontosabb szakmai sikerének. Az itt megadott válaszok árulkodnak a tanítói pályáról, a tanítói munkáról, tevékenységekröl és arról az elképzelésükröl, hogy tanítóként milyen eredményeket érhetnek el, illetve tanítóként mit tartanak elérendő célnak (lásd 3. és 4. ábra).
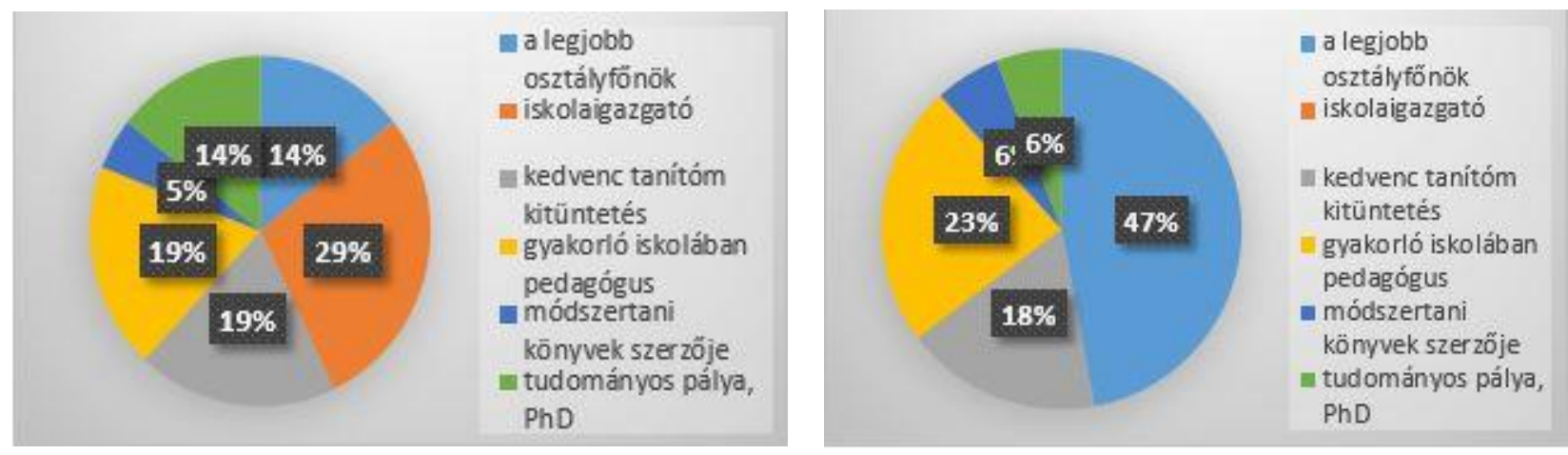


\section{3-4.ábra A tanítóként elérhető legfontosabb szakmai siker a nem partnerségi és partnerségi képzésben résztvevők szerint (2019)}

A hagyományos képzésben résztvevő hallgatók a képzés első félévében nem jártak a gyakorló intézményben, a tanító pályáról alkotott ismereteik saját korábbi élményeikből, tapasztalataikból, megfigyeléseikböl származnak. A legtöbb válaszban (29\%) az iskolaigazgatói pozíció elérése jelent meg legfontosabb szakmai sikerként, szintén nagy arányban (19-19\%) jelent meg a modellként követhető gyakorló iskolai pedagógus, valamint a kedvenc tanítóm cím kiérdemlése. 14-14\%-ot ért el a tudományos pálya és a legjobb osztályfönök elismerés. $A$ friss általános iskolai tapasztalatokkal, s ezáltal a tanítói pályáról reálisabb képpel rendelkező partnerségi képzésben résztvevő hallgatók válaszai között egyáltalán nem jelent meg az iskolaigazgatói pozíció a legfontosabb szakmai sikerek között. A válaszok nagy százalékában a legjobb osztályfőnök (47\%), a gyakorló iskolai pedagógus (23\%) és a kedvenc tanító elismerés (18\%) szerepel.

A pályakép tekintetében végül a tanítói pályához kapcsolódó kudarcról alkotott elképzeléseket vizsgáljuk meg. A pályaválasztás során is fontos szempont lehet, hogy egy-egy szakma esetében mi az, ami veszélyként fogalmazódhat meg, és annak elkerülésére vagy elhárítására az egyén milyen megoldásokat lát, illetve tudja-e hogyan kérhet adott esetben segítséget. Mindezen szempontok közül most azt mutatjuk be, hogy az első éves tanító szakos hallgatók mit szeretnének elkerülni, ha tanítóként dolgoznak, mi az, ami számukra kudarc lenne? (lásd 5. és 6 . ábra)
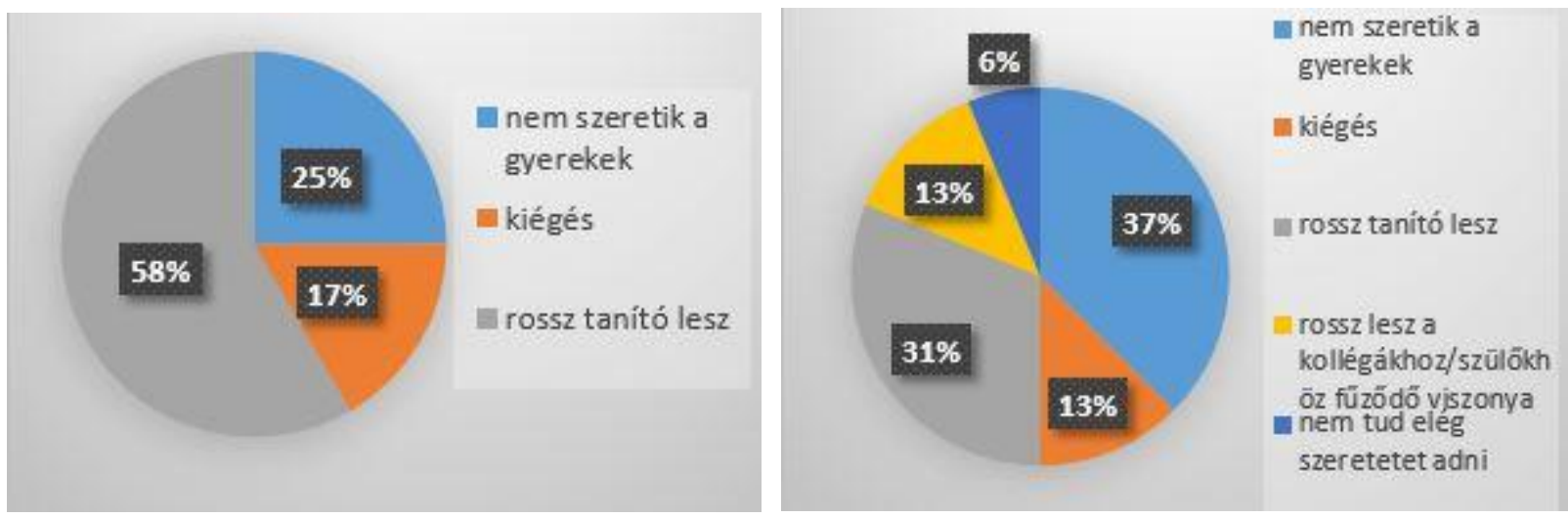

5-6.ábra A tanítóként elkerülendő kudarc a nem partnerségi és partnerségi képzésben résztvevők szerint (2019)

A diagramokon jól látszik a különbség: azok a hallgatók, akik egyetemi tanulmányaik alatt nem vettek részt iskolai gyakorlaton, többségükben attól tartanak, hogy nem szeretik majd őket a gyerekek, illetve rossz tanítók lesznek (nem lesznek képesek a tanulóknak a szükséges ismereteket átadni, a tanulók képességeit megfelelő módon és módszerekkel fejleszteni, nem lesznek elég türelmesek). A partnerségi képzési formában résztvevő hallgatóknál árnyaltabb a kép, kisebb mértékủ a szorosan vett szakmai kudarctól való félelem, és megjelenik a kollégákkal, szülökkel való kapcsolattartás nehézsége. A két csoport közötti különbség a partnerségi hallgatók iskolai hétköznapokban való részvételével magyarázható. A vizsgálatig eltelt három hónap alatt a megkérdezettek 20-24 napot töltöttek az iskolában pedagógiai asszisztensként, és ez alatt a tanítói pályán várható kudarcokról más véleményt formáltak, mint a hagyományos képzésben résztvevő évfolyamtársaik, lényegesen kisebb a félelmük attól, hogy a gyerekek nem fogják szeretni őket.

\section{5. Összegzés}

A duális képzési modell mára országosan ismert és elterjedt képzési forma. Mint az köztudott, a duális képzés előnye, hogy a diploma megszerzésekor már a szakmájuk gyakorlásához szükséges gyakorlati ismeretekkel is rendelkeznek a hallgatók, sőt erre az időpontra többnyire a pályaszocializációjuk is megtörténik. A partnerségi képzési formával még csak ismerkedünk, de 
bevezetését a hallgatók nagyobb arányú gyakorlati képzés iránti igénye, a pedagóguspályát elhagyók nagy aránya, a pályaszocializáció tapasztalható sikertelensége, továbbá az általános iskolákban jelentkező munkaerőhiány indokolta. A tanulmányban bemutatott első felmérés megerősíti, hogy a tanítóképzés partnerségi modellje elősegíti azt, hogy a tanítói életpályáról reális és saját tapasztalatokon alapuló gondolatokat fogalmazzanak meg a hallgatók. A képzési forma nyomon követésével további következtetéseket, célokat és feladatokat fogunk tudni megfogalmazni a tanítóképzésünkkel kapcsolatban.

\section{Köszönetnyilvánítás}

A kutatás az EFOP-3.6.1-16-2016-00006 „A kutatási potenciál fejlesztése és bővítése a Neumann János Egyetemen" pályázat keretében valósult meg. A projekt a Magyar Állam és az Európai Unió támogatásával, az Európai Szociális Alap társfinanszírozásával, a Széchenyi 2020 program keretében valósul meg.

\section{Irodalomjegyzék}

[1] Barabási Tünde 2002: Tanítóképzés rendszere Magyarországon és Romániában. Néhány szerkezeti és tartami komponens összehasonlító vizsgálata. In: Magyar Pedagógia 102. évf. 2. szám 179-201. 179.p.

[2] Barabási Tünde 2008: A tanítói tudás összetevői és fejlesztésük. Kolozsvár.

[3] Szövényi Zsolt 1993: Képzési modellek. Educatio 4. 608-619. 617.p. https://epa.oszk.hu/01500/01551/00006/pdf/636.pdf

[4] Szemerszki Marianna 2018: Belépés a pedagógusképzésbe - Mit mutatnak a felvételi adatok? In: Hera Könyvek V. INNOVÁCIÓ, KUTATÁS, PEDAGÓGUSOK. Szerk.: Endrődy-Nagy Orsolya - Fehérvári Anikó, Budapest, 2018. 299313. http://hera.org.hu/wp-content/uploads/2014/02/HERA_Evkonyvek_V.pdf

[5] Veroszta Zsuzsanna (2015): Pályakép és szelekció a pedagóguspálya választásában. Educatio 1. sz. 47-62. http://epa.oszk.hu/01500/01551/00071/pdf/EPA01551_ecucatio_2015_1_047-062.pdf

[6] Veroszta Zsuzsanna (2015): Pályakép és szelekció a pedagóguspálya választásában. Educatio 1. sz. 47-62. 48.p. http://epa.oszk.hu/01500/01551/00071/pdf/EPA01551_ecucatio_2015_1_047-062.pdf 